\title{
CIÊNCIANATURA
}

\section{Low amplitude and high frequency mechanical stimulation does not affect directly cell differentiation during bone healing}

\author{
Libardo Andrés González Torres, Stephani de Camilo e Alonso, Agnes Batista Meireles
}

Instituto de Ciência e Tecnologia Universidade Federal dos Vales do Jequitinhonha e Mucuri, MG, Brasil

\begin{abstract}
Bone fractures has high incidence numbers and despite all prejudice caused by this kind of injury, some bone healing process features are still unknown. In this work, it is computationally investigated the influence of low amplitude and high frequency mechanical stimulation on cell differentiation during bone healing, using a cell differentiation theory proposed including as mechanical variables strain and flow velocity of interstitial fluid. For this purpose, a finite element model was developed to study three hypothetical situations, aiming at determining in which proportion external mechanical influences bone healing. In the first hypothetical situation, the mechanical stimulus used in the model was computed as $20 \%$ of external mechanical stimulus and $80 \%$ of the stimulus during gait. Similarly, the second hypothetical situation was $50 \%$ external mechanical stimulus and $50 \%$ gait stimulus. Finally, the third hypothetical situation used a proportion of $80 \%$ external mechanical stimulus and $20 \%$ gait stimulus. The results indicated that hypothesis considering high proportions of external stimulation results in unreal delayed healing process and the first hypothetical situation proved to be that which best represents the real process, among the studied cases. From the results obtained in this work, it was concluded that external mechanical stimulation does not affected directly cell differentiation during bone healing. Thus, other processes such as flow of oxygen, nutrients or wastes must be considered.
\end{abstract}

Keywords: Mechanical Stimulus; Bone Healing; Finite Element Method 


\section{Introduction}

Bone fractures is a common kind of injury. The incidence of femoral shaft fractures, for example, range from of 9.5 to 18.9 per 100,000 population annually (NIKOLAOU et al., 2011) and their treatments results in high economic costs, besides the patient's suffering. Nonetheless, the mechanisms by which bone heals, as well as the means by which internal and external factors work together to generate bone healing are still unknown.

Cell migration, proliferation and differentiation involving osteoblasts, chondrocytes or fibroblasts are some processes occurring during bone healing. All these processes depend on multiple factors such as time, mechanical stimulus and vascularization.

An experimental study (CLAES et al., 2008) applied combined distraction/compression stimulus during bone healing of sheep tibia, which resulted in faster healing and a larger and more stable callus. In another experimental study (GOODSHIP et al., 2009), low-magnitude displacements at relatively high frequency were induced on sheep tibia during bone healing, resulting in a greater callus diameter and increased bending strength compared to the non-stimulated control group. Other experimental (PALOMARES et al., 2009; CLAES et al., 2002) and computational (GÓMEZ-BENITO et al., 2001; GARCÍA-AZNAR et al., 2007) studies also reveal that mechanical stimulus can improve and accelerate bone healing. Nevertheless, the way mechanical stimulus influence on bone healing is currently an open question.

This computational study evaluates a mechanobiological hypothesis to investigate the influence of low amplitude and high frequency mechanical stimulation on cell differentiation during bone healing to help to clarify the mechanisms involved in such process.

\section{Bone Healing Process}

Bone is the only tissue that heals without forming a fibrous scar (MARSELL and EINHORN, 2011), instead of it, new bone is developed to replace the damaged one. In order to restore the original shape and functions of a fractured bone, several cellular events such as proliferation, migration and differentiation involving mesenchymal stem cells, cartilage cells, bone cells and fibrous tissue cells. These processes occur in an orchestrated manner driven by the chemical and mechanical microenvironment (GONZÁLEZ-TORRES et al., 2011). The use of flexible fixation systems, generates a proper mechanical microenvironment that stimulates bone healing by secondary bone healing (MARSELL and EINHORN, 2011). Secondary healing is the most common process for bone healing, that involves the formation of an external callus to increase the fracture cross section and therefore its stiffness (ISAKSSON, 2012).

Secondary healing is composed by different overlapping phases, which are represented in Figure 1: hematoma formation, inflammation, fibrocartilaginous callus formation or soft callus stage, ossification or bonny callus formation and bone remodeling. When the bone fracture happens, immediately starts the inflammation phase. The surrounding tissues, the cortical bone, periosteum and blood vessels are disrupted and the osteocytes necrosis begins (GERIS et al., 2008). From then onwards starts the inflammatory response, the necrotic tissue is removed and granulation tissue is formed providing a provisory stabilization callus (DOBLARÉ et al., 2004).

After approximately two weeks, the fibrocartilaginous callus formation begins and the mesenchymal stem cells that migrated to the fracture site during inflammation phase differentiate into chondrocytes, osteoblasts or fibroblasts, depending on mechanical and biochemical conditions (DOBLARÉ et al., 2004). Chondrocytes generates cartilage, which provides mechanical stabilization to the fracture (GERIS et al., 2008), while osteoblasts are responsible for intramembranous bone tissue formation (DOBLARÉ et al., 2004). Differentiation of mesenchymal stem cells into fibroblasts is also possible (GÓMEZ-BENITO et al., 2005). At the end of soft callus phase, chondrocytes are hypertrophyed chondrocytes (DOBLARÉ et al., 2004) and cartilage is mineralized. Then endochondral ossification gradually replaces this cartilaginous callus with bone (MALIZOS and PAPATHEODOROU, 2005).

The third phase of bone healing is bonny callus formation, where just a small gap of non-ossified tissue separates the callus surfaces (CLAES and HEIGELE, 1999). Hypertrophic chondrocytes generated on second phase secrete growth factors that attracts osteocytes, which has the function of degrade the mineralized cartilage allowing the invasion of blood vessels in the calcified cartilage (SHINDELER et al., 2008), essential to hard callus formation (DOBLARÉ et al., 2004). Ossification process continues until all cartilage has been replaced by bone tissue and a bony bridge which grants sufficient stability and stiffness to the fracture gap (DOBLARÉ et al., 2004). Clinical union occurs when the fracture edges are connected by callus (GERIS et al., 2008).

Hard callus is an irregular bone tissue non modelled (SHINDELER et al., 2008). After ossification, bone remodeling occurs, so as to restore the original shape and structure of the bone (DOBLARÉ et al., 2004). Initially, bone resorption is followed by the transformation of irregular callus bone tissue into lamellar bone, while the neovascularization process remains constant until bone supply return to normal conditions (GERIS et al., 2008). All these biological events enclose bone healing process and restore the fractured bone to its primary shape and functions. 
Figure 1- Four stages of secondary healing on a fractured bone. Adapted from (MARIEB, 2006)

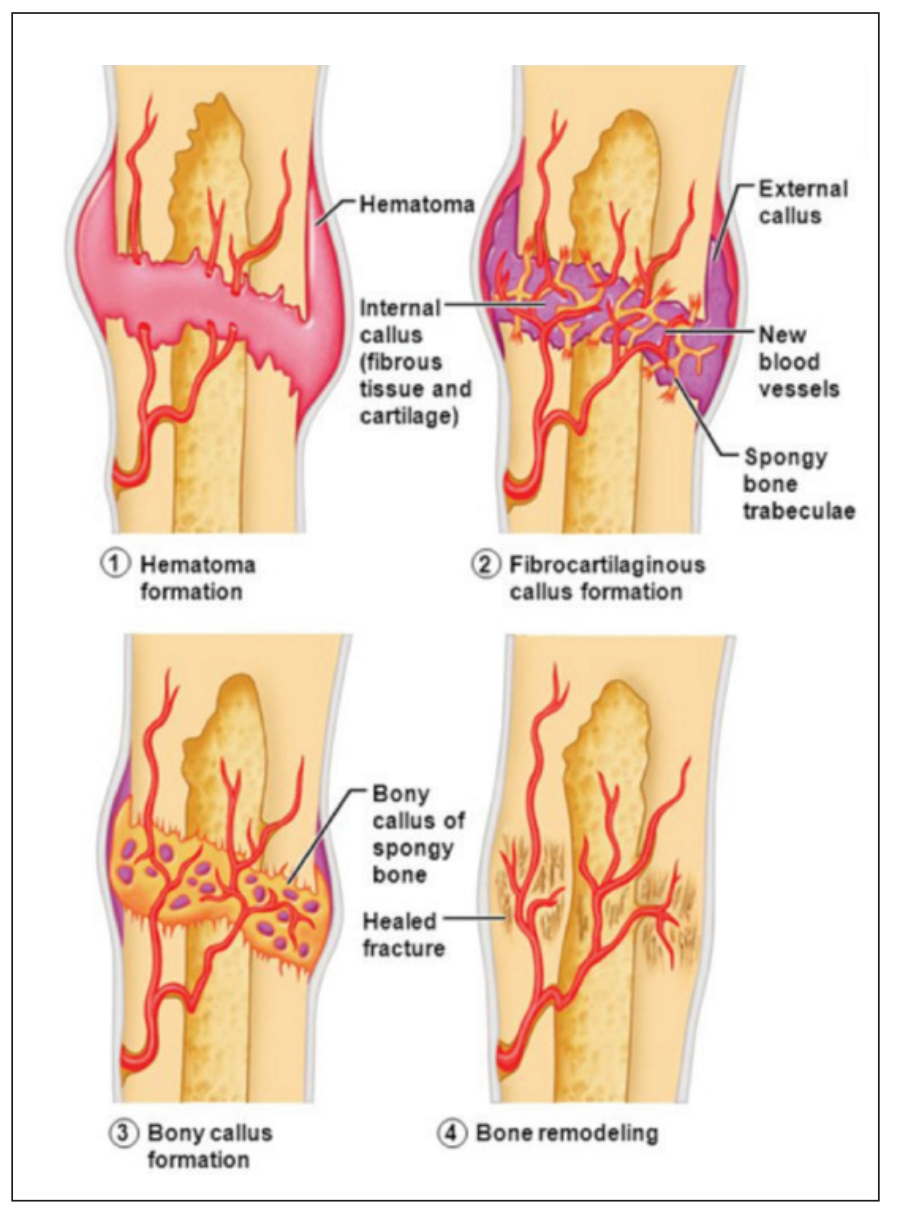

When studying biological processes, it should be considered that such processes depend on many internal and external factors that directly or indirectly influence on its outcome. Genetic, cellular and biochemical factors, patient age, type of fracture, interfragmentary movement, fracture geometry, among other factors work together to influence bone regeneration decisively (GÓMEZ-BENITO et al., 2005). In some studies, was observed that flexible fixations increased callus formation, while the rigid fixations limit the stimulation of callus formation (ISAKSSON, 2012; EPARI et al., 2010). The callus formation is important, because its biomechanical function is to reduce the initial movement to enable the union of bone fragments with bony bridges. Lacroix and Prendergast (2002) classify the types of differentiation according to the levels of biophysical stimulation. According to their study, high stimulus levels favours differentiation into fibroblasts, intermediate levels favours chondrocytes and low levels favours osteoblasts. The mechanical condition of the fracture zone regulates the formation of intramembranous and endochondral bone in callus and these conditions are constantly altered by changes in geometry and tissue stiffness (WILSON et al., 2015). A previous study (ZHANG et al., 2012) concluded that the mechanical environment to which the fracture was submitted strongly influenced the size and shape of callus. Changes in callus components depended on the time led to corresponding changes in the mechanical properties and stability of the fracture (ZHANG et al., 2012). Vascularization is essential for bone regeneration. Angiogenesis is described using equations that depends on angiogenic growth factors relative to osteoblasts and cartilage, in addition to consider the natural production decay of these growth factors (GERIS et al. 2008).

Prendergast et al. (1997) introduced a tissue differentiation model based on a biphasic poroelastic finite element model of tissues and proposed two biophysical stimulus as mechanical variables: shear displacement (deviatoric) on the solid phase and fluid velocity in the interstitial fluid phase (ISAKSSON, 2012). According to this theory, high deviatoric displacement and fluid velocity magnitudes stimulate the differentiation into fibrous tissue, whereas if both stimuli are low, bone formation may occur. Later, Lacroix and Prendergast (2002) have applied this theory on a finite element model able to predict slower symmetrical 2D regeneration with increasing size of the fracture gap and increased production of connective tissue with increased interfragmentary displacement.

Thus, the present work look for computationally study whether or not external mechanical stimulation of low magnitude and high frequencies directly influence on the healing process, with the purpose of deepen in the understanding of the process. 


\section{Material and Methods}

Cell differentiation, migration and proliferation can be mathematically represented by conservation equations applied to cell concentrations. Equations (1) to (5) represent the cellular dynamics in the bone fracture callus with a simplified model. Tissue densities are considered proportional to cell concentration.

$$
\begin{aligned}
& \frac{\partial c_{S}}{\partial t}=\nabla\left(D_{S} \nabla c_{S}\right)+\alpha p\left(\frac{\psi}{\psi+\psi_{r e f}}\right)-k_{S}^{b} M^{b} c_{S}-k_{S}^{c} M^{c} c_{S}-k f M^{f} c_{S} \\
& \frac{\partial c_{b}}{\partial t}=k_{h}^{b} F_{h}^{b} c+k_{S}^{b} M^{b} c_{S} \\
& \frac{\partial c_{c}}{\partial t}=-k_{c}^{h} F_{c}^{h} c_{c}+k_{S}^{c} M^{c} c_{S} \\
& \frac{\partial c h}{\partial t}=k_{c}^{h} F_{c}^{h} c_{c}-k_{h}^{b} F_{h}^{b} c_{h} \\
& \frac{\partial c f}{\partial t}=k_{S}^{f} M^{f} c_{S}
\end{aligned}
$$

where $\frac{\partial c}{\partial t}$ represent the concentration rates of each cell type $(\mathrm{s}=$ stem cells; $\mathrm{b}=$ bone cells; $\mathrm{c}=$ cartilage cells; $\mathrm{h}=\mathrm{hyper}-$ trophied cartilage cells; $\mathrm{f}=$ fibrous tissue cells); $\mathrm{D}_{\mathrm{s}}$ represents mesenchymal stem cells diffusion which depends on granulation tissue concentration; $\alpha_{p}$ is a parameter that describe the velocity of mesenchymal stem cells proliferation; $k_{i}^{j}$ represents the differentiation velocity from cell $i$ to cell $j ; \mathrm{M}$ and $\mathrm{F}$ represent cell maturation (functions with the value 0 or 1 ); $c_{i}$ is the concentration of cell $i ; \psi$ is the mechanical stimulus. Detailed explanation of Conservation Law for cells and parameters are presented in Appendix A.

Equation (6) represents angiogenesis, where $D_{f}$ is the velocity coefficient of disrupted tissue and $\mathrm{v}$ is the vascularization level that depends on the mechanical stimulation. Thus, after perform analysis and considerations, based on Geris et al. [13], was used $D f=3 \mathrm{~m}^{2} / \mathrm{s}$.

$$
\frac{\partial v}{\partial t}=D f \nabla^{2} v
$$

The model presented was implemented in the software Abaqus v.6.12. The purpose was to investigate the influence of low amplitude and high frequency mechanical stimulation on cell differentiation during bone healing. To do that it was considered the cell differentiation law proposed by Prendergast et al. (1997), which considers cell differentiation is regulated by the deviatoric shear strain and the velocity on interstitial fluid in tissues. Thus, it was chosen a biphasic material model to represent the tissues. The mechanical stimulus, $\psi$, was computed by using the Equations (7) and (8).

$$
\begin{gathered}
\psi=J_{2}+a \frac{v F}{b} \\
J_{2}=\sqrt{\left(\varepsilon_{I}-\varepsilon_{O c t}\right)^{2}+\left(\varepsilon_{I I}-\varepsilon_{O c t}\right)^{2}+\left(\varepsilon_{I I I}-\varepsilon_{O c t}\right)^{2}}
\end{gathered}
$$

where $\psi$ is the mechanical stimulus, which depends on the localization and time; $v F$ is the relative interstitial fluid velocity on extracellular solid matrix; $a=0,0375 ; b=3 \mu \mathrm{m} / \mathrm{s}$ (PRENDERGAST et al., 1997). $J_{2}$ is the second invariant of the deviatoric stress tensor; $\varepsilon_{I}, \varepsilon_{I}, \varepsilon I I I$ are the principal strains and $\varepsilon_{\text {oct }}$ is the octahedric strain.

Tissue differentiation was considered to depend on vascularization and mechanical stimulus [8] (Eq. 9). Mesenchymal stem cells can differentiate directly into osteoblasts, if the mechanical stimulus is adequate and the vascularization level is higher than a minimum value. When the vascularization conditions do not favor differentiation towards osteoblasts, mesenchymal cells differentiate either into chondrocytes or fibroblasts, according to the mechanical stimulus levels presented by Equation 
(9). It is important to note that cells maturation time was considered, which is detailed in Appendix A.

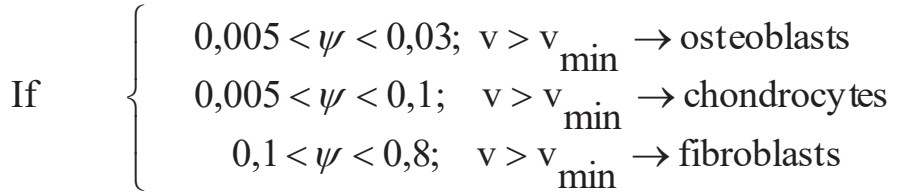

The finite element model implemented in the software Abaqus v6.12 was used to solve the equations of the model in a two dimensional geometry, which represents the callus of a sheep metatarsus. The geometry was a quarter of the callus (Figure 2), considering symmetry in the plane of the fracture, and also axial symmetry, the dimensions were extracted from similar geometries used in literature (GONZÁLEZ-TORRES et al., 2011). The load and boundary conditions were considered as axial loading of the metatarsus due to the activities of sheep or external stimulation (Figure 2).

The mesh was composed by 769 linear squared elements with 839 nodes. As initial conditions, it is considered the fracture gap composed by granulation tissue, the cortical bone fully vascularized, a saturation of stem cells in the periosteum, while the concentration and density of other cells and tissues is considered null in the fractured region. The boundary conditions for the flow of interstitial fluid are indicated in Figure 2. The frequency of external mechanical stimulus is $90 \mathrm{~Hz}$ (GÓMEZ-BENITO et al., 2001; GÓMEZ-BENITO et al., 2005; MALIZOS and PAPATHEODOROU, 2005). Concentration of cells was normalized between 0 and 1 . Zero represents null concentration and one the maximum concentration.

Figure 2- Transversal section of a fractured bone with symmetry and revolution axes, including the fracture callus and the interfragmentary space (above the horizontal symmetry axis). The mesh of quadrilateral elements used in the model, the applied loads (in red) and the boundary conditions of flux are presented

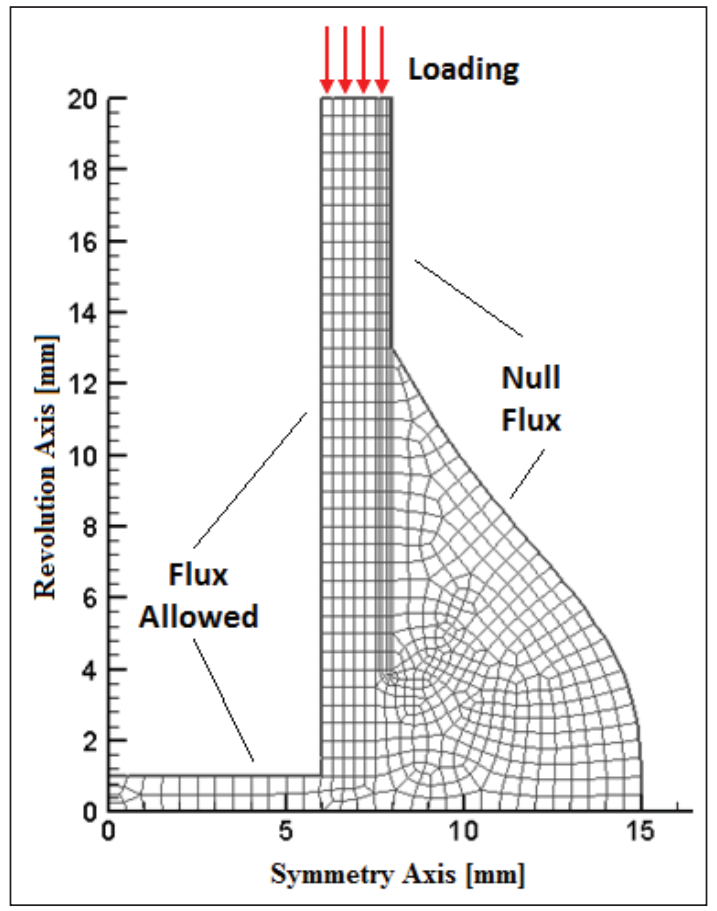

\section{Results}

The interfragmentary deformation used in the simulations adapt according to the variations in the conditions of the fractured zone, which changes with time due to several factors such as mechanical stimulation, changes of histological characteristics, among others. The amplitude of interfragmentary movement decreases with time due to the instability of the fractured region that decreases as the mechanical stimulus decreases. In the first simulation, a frequency of 1Hz (GÓMEZ-BENITO et al., 2005) was applied, simulating the in vivo gait.. Aiming to verify the accuracy of our model, in Figure 3 the results of the computational simulation obtained with this study was compared with experimental results of interfragmentary movement in a sheep, obtained by Claes and Heigele (1999). 
Figure 3- Evolution of interfragmentary movement in computational simulation compared with the experimental results in a sheep (CLAES and HEIGELE, 1999)

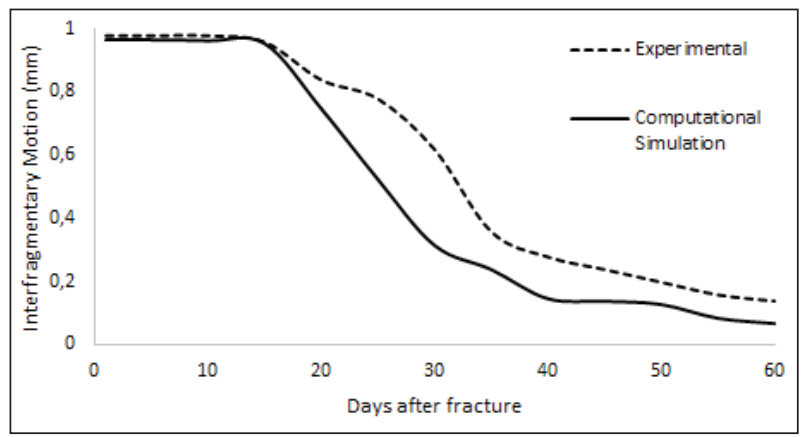

Figure 4- Concentration of bone cells in fraction (from 0 to 1 ) comparing different hypothesis of stimulus. More realistic results are presented in A, where the external mechanical stimulus has the lower influence (20\%). B and C present non realistic results, with influence external stimulus of the $50 \%$ and $80 \%$, respectively

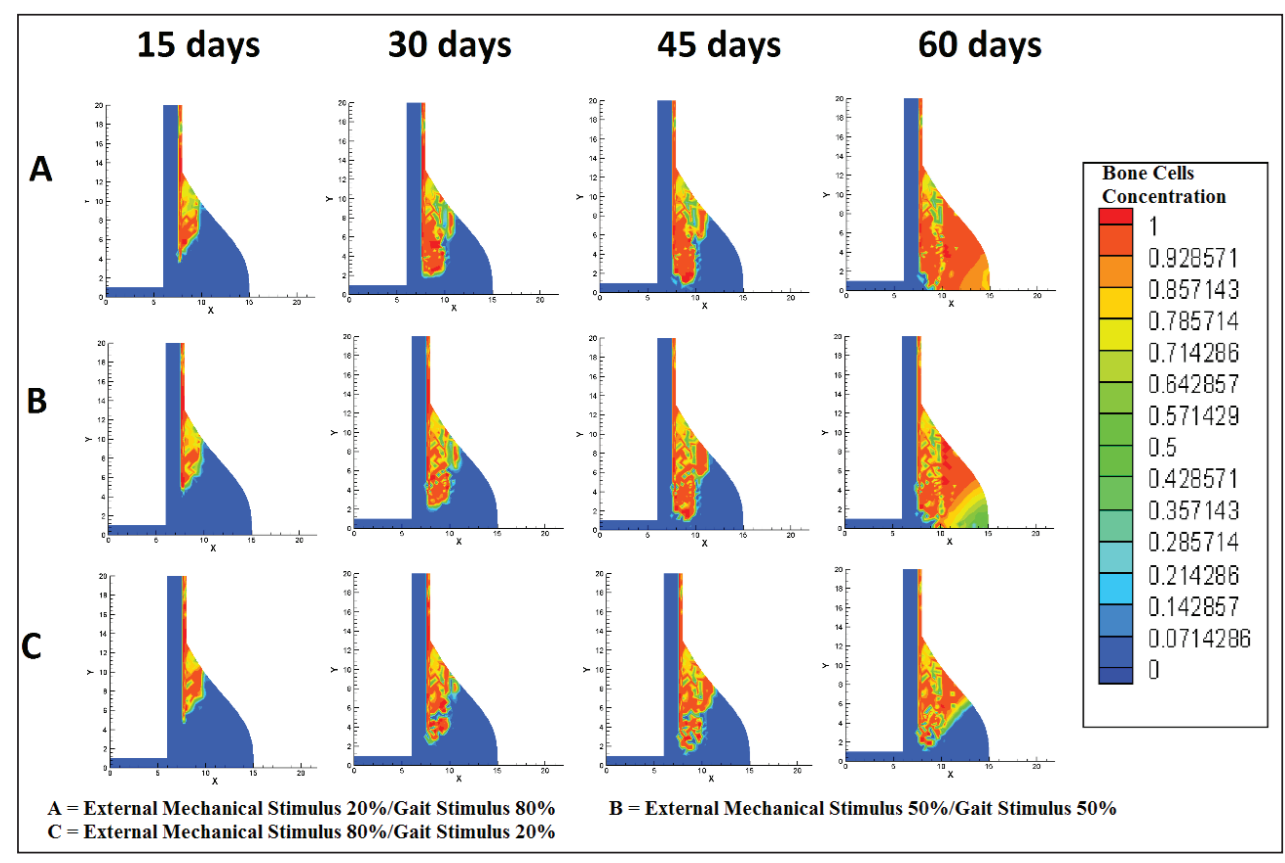

Simulations involving external mechanical stimulus were performed, after obtain results from the model close to experimental ones (Fig. 3). First, it was investigated in which proportion external mechanical stimulus could effectively influence on bone healing, for this purpose, three hypothetical proportions were established: hypothesis A - 20\% for the external mechanical stimulus and $80 \%$ for the gait stimulus; hypothesis B - 50\% for the external mechanical stimulus and 50\% for the gait stimulus and hypothesis C - $80 \%$ for the external mechanical stimulus and $20 \%$ for the gait stimulus. The frequency of external mechanical stimulus was $90 \mathrm{~Hz}$ and the frequency considered for gait is $1 \mathrm{~Hz}$. The results of simulations correspondent to the three hypotheses during 60 days are shown in Figure 4.

During the first week of simulation only the gait stimulus was considered, since it is the inflammatory stage and the fracture site is still very unstable to tolerate external stimulation. From the 7 th day to the 21 st day a combination of external mechanical stimulus and gait was applied, according to the situations previously presented. This period corresponds to the soft callus stage, in which the mesenchymal stem cells differentiate into bone cells, cartilage cells and fibrous tissue cells. After day $21^{\text {th }}$, during hard callus and remodeling stages only gait stimulus was considered, since this work was focused on the study of the influence of an external mechanical stimulus when cell differentiation is happening.

An additional simulation was executed to investigate the influence of the duration of the mechanical stimulation. Bone healing evolution only considering the stimulation from gait (Figure 5A) was compared with bone healing evolution with a 
combined external and gait stimulation (Figure 5B). The combined stimulation was considered from the 7 th day to the $21 \mathrm{st}$ day. During this period, a combination of 17 minutes $(1020$ seconds, $90 \mathrm{~Hz}$ ) of external stimulus (GOODSHIP and KENWRIGHT, 1985) and 8.5 hours (30600 seconds, $1 \mathrm{~Hz}$ ) of gait per day (POKORNÁ et al., 2013) was considered. In the first week of simulation and from the 22nd day to the 60th day again only stimulation from gait was considered.

Figure 5- Concentration of bone cells in fraction (from 0 to 1 ) comparing different hypothesis of stimulus. (A) Results obtained only with gait stimulation. (B) Results considering the proportion of application time for simultaneous external and gait stimulation (from 7th day to 21th day). Not significant differences are observed between both situations

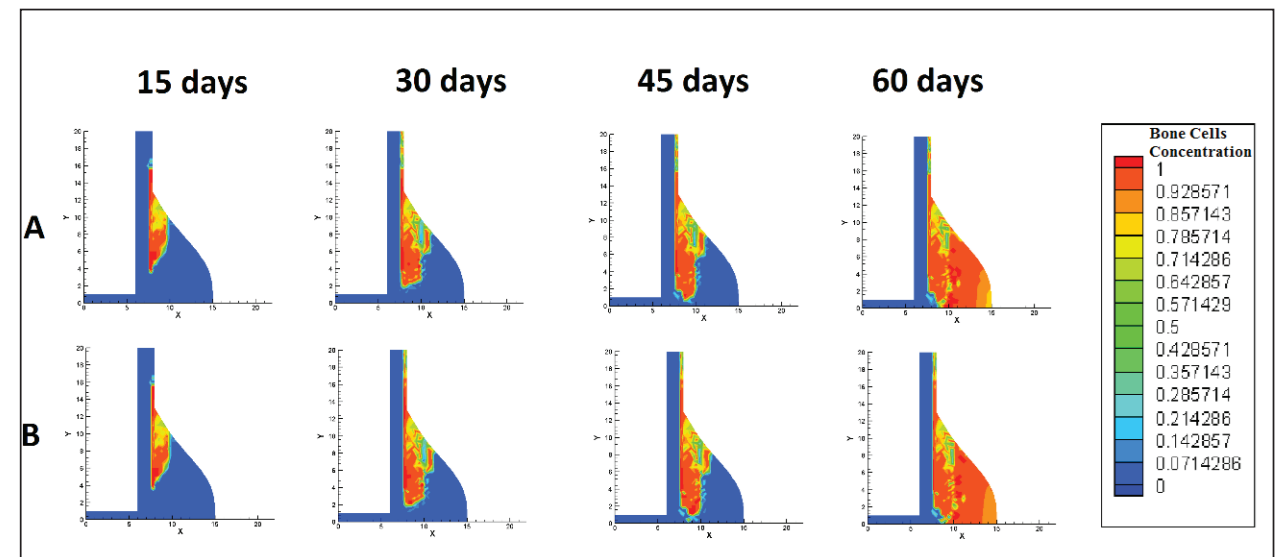

\section{Discussion}

It is known that mechanical stimulation can affect positively and even accelerate bone healing process (CLAES et al., 2008; GÓMEZ-BENITO et al., 2001; GOODSHIP and KENWRIGHT, 1985; EBRAHIMI et al., 2012). This work aimed at better understanding how mechanical stimulation affects bone regeneration process, focusing on the investigation of the the role of low amplitude and high frequency mechanical stimulation in cell differentiation during bone fracture healing.

In order to compare this model with experimental studies, the results were compared to the reported interfragmentary movement in sheep (CLAES and HEIGELE, 1999). The model proposed in this study proved to agree with these experimental results, thus it was possible to continue with the computational experiments of situations presented in this article. However, some simplifications had to be considered in the model, the axial loading was the only force considered, despite is not the only one present in the fracture region, it has the more significant magnitude (GONZÁLEZ-TORRES et al., 2011). Other simplification was that the model did not consider tissue equations and cell hypertrophy and that growth factors and cytokines, substances that are necessary for different events occurring during bone healing (GERIS et al., 2008), were not explicitly included in the model. Even so, as all the simulated cases involved the same characteristic it is possible to compare the results from them and to extract valid conclusions.

The first group of simulations was aimed at verifying in which proportion of external mechanical stimulation and gait stimulation more realistic cell differentiation patterns were predicted. Thereby, as described in the previous section, three different cases were evaluated and as shown in Figure 4, high proportions of external stimulation artificially delay the healing process, probably because excessive mechanical stimulation difficult bone synthesis. More realistic results were observed for the lowest weight $(20 \%)$ was attributed to external stimulation.

Simulations considering the proportion of the time in which forces are applied (Fig. 5) reveal no significant changes in bone healing evolution between the two studied cases. Comparing the results obtained from the simulations with experimental studies (GOODSHIP et al., 2009; GOODSHIP et al., 1985), they are more similar to the experimental radiographs when low influence of external mechanical stimulation is considered.

Bone healing is a complex and intriguing process that has been studied by many scientists aiming at understanding and contribute with the improvement of methods and techniques to accelerate the regeneration of bone fractures. Although, the way in which the process is influenced by all internal and external factors remain unknown.

From the results obtained in this work, it can be concluded that low amplitude and high frequency mechanical stimulation does not affect directly cell differentiation during bone healing. Other processes such as diffusion of nutrients and wastes or even growth factors and cytokines, or the promotion of proliferation of cells, can be other ways as external mechanical stimulation modify the bone healing process. Therefore, it is still necessary to understand more deeply the biological mechanisms which works during bone healing processes.. Thus, this field of study requires further investigation. 


\section{Acknowledgment}

We thank the Brazilian agencies CNPq, FAPEMIG and PRPPG (UFVJM) for their financial support and Prof. Msc. Arlindo Follador Neto for his fundamental technical support at the beginning of this work.

\section{References}

CLAES L, AUGAT P, SCHORLEMMER S, KONRADS C, IGNATIUS A, EHRNTHALLER C. Temporary distraction and compression of a diaphyseal osteotomy accelerates bone healing. J. Orthop. Res. 2008;26:772777.

CLAES L, GRASS R, SCHMICKAL T, KISSE B, EGGERS C, GERNGROSS H, et al. Monitoring and healing analysis of 100 tibial shaft fractures. Langenbeck's Archives of Surg. 2002;387:146-152.

CLAES L, HEIGELE, C. Magnitudes of local stress and strain along bony surfaces predict the course and type of fracture healing. J. Biomech. 1999;32:255- 266.

DOBLARÉ M, GARCÍA-AZNAR J, GÓMEZ-BENITO M. Modelling bone tissue fracture and healing: a review, Eng. Frac. Mech. 2004;71:1809-1840.

EBRAHIMI H, RABINOVICH M, VULETA V, ZALCMAN D, SHAH S, DUBOV A, et al. Biomechanical properties of an intact, injured, repaired, and healed femur: An experimental and computational study. J. Mech. Behav. Biomed. Mater. 2012;16:121-135.

EPARI D, DUDA G, THOMPSON M. Mechanobiology of bone healing and regeneration: in vivo models. Proc Inst Mech Eng H. 2010;224:1543-1553.

GARCÍA-AZNAR J, KUIPER J, GÓMEZ-BENITO M, DOBLARÉ M, RICHARDSON J. Computational simulation of fracture healing: Influence of interfragmentary movement on the callus growth. J. Biomech. 2007;40:14671476.

GERIS L, GERISCH A, SLOTEN J, WEINER R, OOSTERWYCK H. Angiogenesis in bone fracture healing: A bioregulatory model. J. Theor. Biol. 2008;251:137-158.

GÓMEZ-BENITO M, GARCÍA-AZNAR J, KUIPER J, DOBLARÉ M. Influence of fracture gap size on the pattern of long bone healing: a computational study. J. Theor. Biol. 2005;235:105-119.

GÓMEZ-BENITO M, GONZÁLEZ-TORRES L, REINA-ROMO E, GRASA J, SERAL B, GARCÍA-AZNAR J. Influence of high-frequency cyclical stimulation on the bone fracture-healing process: mathematical and experimental models. Phil. Trans. 2001;369:4278-4294.

GONZÁLEZ-TORRES L, GÓMEZ-BENITO M, GARCÍA-AZNAR J. Evaluation of residual stresses due to bone callus growth: a computational study. J. Biomech. 2011;44:1782-1787.

GOODSHIP A, KENWRIGHT J. The influence of induced micromovement upon the healing of experimental tibial fractures. J. Bone Joint Surg. 1985;67B:650-655.

GOODSHIP A, LAWES T, RUBIN C. Low-magnitude high-frequency mechanical signals accelerate and augment endochondral bone repair: preliminary evidence of efficacy. J. Orthop. Res. 2009;27:922-930.

ISAKSSON H. Recent advances in mechanobiological modeling of bone regeneration, Mech. Res. Commun. 2012;42:22-31.

LACROIX D, PRENDERGAST P. A mechano-regulation model for tissue differentiation during fracture healing: analysis of gap size and loading. J. Biomech. 2002;35:1163-1171. 
MALIZOS K, PAPATHEODOROU L. The healing potential of the periosteum: Molecular aspects. Injury. 2005;36:S13-S19.

MARIEB E. Essentials of Human Anatomy and Physiology. 8th ed. San Francisco. Benjamin Cummings; 2006.

MARSELL R, EINHORN T. The biology of fracture healing. Injury. 2011;42:551- 555.

NIKOLAOU V, STENGEL D, KONINGS P, KONTAKIS G, PETRIDIS G, PETRAKAKIS G, et al. Use of femoral shaft fracture classifi-cation for predicting the risk of associated injuries. J. Orthop. 2011;25:556-559.

PALOMARES K, GLEASON R, MASON Z, CULLINANE D, EINHORN T, GERSTENFELD L, et al. Mechanical Stimulation Alters Tissue Differentiation and Molecular Expression during Bone Healing. J. Orthop. Res. 2009;27:1123-1132.

POKORNÁ P, HEJCMANOVÁ P, HEJCMAN M, PAVLŮ V. Activity time budget patterns of sheep and goats cograzing on semi-natural species-rich dry grassland.Czech J. Anim. Sci. 2013;58:208-216.

PRENDERGAST P, HUISKES R, SOBALLE K. Biophysical stimulus on cells during tissue differentiation at implant interfaces. J. Biomech. 1997;30:539- 548.

SCHINDELER A, MCDONALD M, BOKKO P, LITTLE D. Bone remodeling during fracture repair: The cellular picture, Semin. Cell Dev. Biol. 2008;19:459-466.

WILSON C, MSCHUETZ M, EPARI D. Effects of strain artefacts arising from a pre-defined callus domain in models of bone healing mechanobiology. Biomech. Model. Mechanobiol. 2015;4:1129-1141.

ZHANG L, RICHARDSON M, MENDIS P. Role of chemical and mechanical stimulus in mediating bone fracture healing. Clin. Exp. Pharmacol. Physiol. 2012;39:706-710.

\section{APPENDIX A}

Equation (A.1) is the Conservation Law for Cells:

$$
\frac{\partial c_{i}}{\partial t}=\overbrace{\nabla\left(D_{i} \nabla_{c i}\right)}^{\text {Migration }}+\overbrace{F_{p}^{i}\left(c_{i}, \psi\right)_{c_{i}}}^{\text {Proliferation }}-\overbrace{\sum_{j \neq i}^{c e l l K_{l}} K_{l}^{j}\left(c_{j}, v, \psi, t\right)_{c}}^{\text {Differentiation } \cdot \text { to } \cdot \text { other } \cdot \text { cells }}+\overbrace{\sum_{j \neq i}^{c e l l s} K_{j}^{i}\left(c_{j}, v, \psi, t\right)_{c}}^{\text {Differentiation } \cdot \text { from } \cdot \text { other } \cdot \text { cells }}
$$

where $c_{i}$ is the cell concentration for cell type i, $D_{i}$ is the diffusion coefficient; $F_{p}^{i}\left(c_{i}, \psi\right)$ is the proliferation function which depends on cell concentration $\left(c_{i}\right)$ and mechanical stimulus $(\psi) ; K^{i}{ }_{j}(c j, v, \psi, t)$ is the differentiation rate of cell type $\mathrm{i}$ into cell type $\mathrm{j}$ which depends on cell concentration $\left(c_{j}\right)$, vascularization level $(v)$, mechanical stimulus $(\psi)$ and time $(t)$.

The equations used in this model depend on several parameters and some of them are defined in Table A.1. 
Table A.1. Parameters

\begin{tabular}{|c|c|c|c|}
\hline Parameter & Value & Description & Reference \\
\hline$K_{S}^{b}, K_{S}^{c}, K_{S}^{c h}, K_{S}^{f}$ & 1 day & $\begin{array}{l}\text { Osteoblasts, chondrocytes, hypertrophic } \\
\text { chondrocytes and fibroblasts differentiation } \\
\text { constants }\end{array}$ & (GERIS et al., 2008) \\
\hline$\alpha_{p}$ & $0.85 d a y^{-1}$ & Mesenchymal stem cell proliferation & (GARCÍA-AZNAR et al. ,2007) \\
\hline$\psi_{\text {ref }}$ & 0.2 & $\begin{array}{l}\text { Mechanical stimulus necessary } \\
\text { mesenchymal stem cell proliferation }\end{array}$ & (GARCÍA-AZNAR et al. ,2007) \\
\hline$D_{s}$ & $1 \mathrm{~mm}^{2} /$ day & $\begin{array}{l}\text { Migration coefficient for mesenchymal } \\
\text { stem cell }\end{array}$ & (GARCÍA-AZNAR et al. ,2007) \\
\hline$M^{C}$ & 17 days & Maturation time for chondrocytes & $\begin{array}{l}\text { (GERIS et al., 2008; GARCÍA- } \\
\text { AZNAR et al. ,2007) }\end{array}$ \\
\hline$M^{b}$ & 1 day & Maturation time for fibroblasts & $\begin{array}{l}\text { (GERIS et al., 2008; GARCÍA- } \\
\text { AZNAR et al. ,2007) }\end{array}$ \\
\hline$M^{f}$ & 15 days & Maturation time for fibroblasts & $\begin{array}{l}\text { (GERIS et al., 2008; GARCíA- } \\
\text { AZNAR et al. ,2007) }\end{array}$ \\
\hline$F_{c}^{h}$ & 20 days & $\begin{array}{llll}\begin{array}{l}\text { Maturation time } \\
\text { chondrocytes }\end{array} & \text { for hypertrophic } \\
\end{array}$ & $\begin{array}{l}\text { (GERIS et al., 2008; GARCÍA- } \\
\text { AZNAR et al. ,2007) }\end{array}$ \\
\hline
\end{tabular}

\footnotetext{
Libardo Andrés González Torres

Instituto de Ciência e Tecnologia Universidade Federal dos Vales do Jequitinhonha e Mucuri, MG, Brasil

E-mail: 1.gonzales@ict.ufvjm.edu.br
}

Participação do autor:

Orientou o trabalho, auxiliou na escrita do artigo e na modelagem matemática.

\section{Stephani de Camilo e Alonso}

Instituto de Ciência e Tecnologia Universidade Federal dos Vales do Jequitinhonha e Mucuri, MG, Brasil

E-mail: stephanyengmec@gmail.com

Participação do autor:

Realizou o trabalho computacional e escreveu o artigo.

\section{Agnes Batista Meireles}

Programa de Pós graduação em Ciências Farmacêuticas da Universidade Federal dos Vales do Jequitinhonha e Mucuri, MG, Brasil E-mail: agnesabm@gmail.com

Participação do autor:

Ajudou nos aspectos biológicos do trabalho e auxiliou na escrita do artigo. 